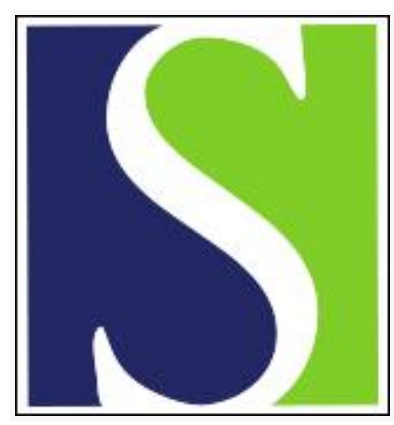

Scand J Work Environ Health 2004;30(1):30-35

https://doi.org/10.5271/sjweh.762

Issue date: Feb 2004

Exposure to persistent organochlorine compounds through fish consumption and the incidence of osteoporotic fractures

by Wallin E, Rylander L, Hagmar L

Affiliation: Department of Occupational and Environmental Medicine, Lund University Hospital, SE 22185 Lund, Sweden. ewa.wallin@ymed.lu.se

Refers to the following texts of the Journal: 1995;21(2):96-105 1995;21(6):419-426

Key terms: exposure; fish consumption; fisherman; fracture; incidence; osteoporosis; osteoporotic fracture; PCP; persistent organochlorine compound; polychlorinated biphenyl

This article in PubMed: www.ncbi.nlm.nih.gov/pubmed/15018026 


\title{
Exposure to persistent organochlorine compounds through fish consumption and the incidence of osteoporotic fractures
}

\author{
by Ewa Wallin, $R N,{ }^{1}$ Lars Rylander, PhD, ${ }^{1}$ Lars Hagmar, $M D^{1}$
}

\begin{abstract}
Wallin E, Rylander L, Hagmar L. Exposure to persistent organochlorine compounds through fish consumption and the incidence of osteoporotic fractures. Scand J Work Environ Health 2004;30(1):30-35.
\end{abstract}

\begin{abstract}
Objectives Animal studies have shown that persistent organochlorine compounds (POC) impair normal bone metabolism and result in increased bone fragility. These findings may have health implications for POC-exposed human populations. The aim of the present study was to assess the impact of POC-contaminated fish on the selfreported fracture incidence of Swedish fishermen and their wives.

Methods A postal questionnaire was sent to 2096 fishermen and 1602 fishermen's wives from the Swedish east (exposed) coast and 4584 fishermen and 4217 fishermen's wives from the west (unexposed) coast. Self-reported fractures, together with specified current fish consumption and information about potential confounders, were registered. The response rates varied between 50\% and 59\%. The age distributions of the nonrespondents and respondents were almost identical. Hip, vertebral, and wrist fractures were classified as osteoporotic. The fracture incidence rates for specific skeletal locations were based on allocated fractures and person-years under risk from the age of 25 years until the time of fracture or the end of follow-up.

Results No differences in fracture incidence were observed between the east and west-coast cohorts. East-coast wives with more than one meal of fatty fish from the Baltic Sea per month had, however, an increased fracture incidence as compared with that of the east-coast wives who ate, at most, one such meal per month (age-adjusted incidence rate ratio $1.68,95 \%$ confidence interval 1.00-2.84). No such exposure-response association was found for the fishermen.

Conclusions The present study only minimally supports an association between POC exposure through contaminated fish and an increased risk of osteoporotic fractures.
\end{abstract}

Key terms fish consumption, fishermen, fractures, osteoporosis, polychlorinated biphenyls (PCB).

The high incidence of osteoporotic fractures is an important public health problem, especially in western societies with aging populations (1-3). The reasons for an observed increase in fracture incidence during the last few decades are not well known, but changes in environmental factors may be important $(4,5)$.

Animal studies show that some persistent organochlorine compounds (POC) may impair bone metabolism. 2,3,7,8-Tetrachlorodibenzo- $p$-dioxin (TCDD) has been shown to inhibit tibial growth in rat in a dose-dependent manner (6). Moreover, 3,3',4,4',5-pentachlorobiphenyl (PCB-126), which is a dioxin-like compound, impaired the mineralization process of tibiae in rat (7) and also reduced the collagen content and serum osteocalcin levels, which resulted in impaired maximum torque and stiffness of the humerus (8). Furthermore, the trabecular bone density in Baltic gray seal was lower during the 1970s, the period of maximum POC contamination in the Baltic Sea off the Swedish east coast, as compared with the density during both a preceding period and the later period (9).

The mechanisms for POC-related impairment of normal bone metabolism are not well known. Bone is a target tissue for estrogens, and the estrogen deficiency associated with menopause is the cause of the most rapid phase of bone loss in women (10). Moreover, estrogens seem to be involved in maintaining the male skeleton (11). Thus one possible hypothesis is that dioxins or other POC act as endocrine disruptors and modulate the homeostasis of estrogens or other steroid hormone systems (12).

High accidental exposure to a POC, hexachlorobenzene, resulted in severe osteoporosis (13), and infants exposed in utero to high concentrations of PCB and

1 Department of Occupational and Environmental Medicine, Lund University Hospital, Lund, Sweden.

Reprint requests to: Ms Ewa Wallin, Department of Occupational and Environmental Medicine, Lund University Hospital, SE-221 85 Lund, Sweden [E-mail: ewa.wallin@ymed.lu.se] 
dibenzofurans developed irregular calcification of their skull bones (14). Thus exposure to high POC levels may also impair normal bone metabolism in humans. The pertinent question is whether lower POC exposure levels may also be harmful to the human skeleton.

In Sweden, the consumption of fatty fish from the Baltic Sea is the single major dietary source of POC (15-17). Professional fishermen from the Swedish east and west coasts, as well as their wives, eat almost twice as much fish as referents from the general population $(17,18)$. East-coast fishermen average higher plasma levels of dioxin-like POC (290 pg/g lipid) than both west-coast fishermen (139 pg/g lipid) and men from the general Swedish population (123 pg/g lipid) (17). This discrepancy is a result of fish from the west coast having been much less contaminated with POC (19). Eastcoast fishermen have been shown to have more than three times higher plasma levels of the sum of $10 \mathrm{PCB}$ congeners (1996 ng/g lipid) than fishermen's wives from the same coastal stretch $(588 \mathrm{ng} / \mathrm{g}$ lipid) $(17,20)$. The body burden of POC decreases in women with lactation (21), and this phenomenon is one of the major reasons for the differences in plasma levels between men and women. PCB contributed about $80 \%$ of the dioxin-like POC exposure from Baltic Sea fatty fish (16).

Through linkage with the Swedish Fracture Register at the National Board of Health and Welfare, we have recently shown that east-coast fishermen's wives have a significantly increased incidence for hospitalized vertebral fractures when compared with west-coast fishermen's wives [incidence rate ratio (IRR) 2.29, 95\% confidence interval (95\% CI) 1.23-4.28], and we observed a similar, but nonsignificant, tendency for their husbands (IRR 1.45, 95\% CI 0.74-2.84) (22). A weakness with the register study was the lack of individual exposure data and potential confounders.
The aim of our present study was to assess the impact of POC-contaminated fish on the self-reported fracture incidence of cohorts of Swedish fishermen and their wives.

\section{Participants and methods}

\section{Cohorts}

Previously established cohorts of professional fishermen and their wives from the Swedish east and west coasts $(17,18)$ were linked to the National Cause-of-death Register at Statistics Sweden, and vital status was determined as of 31 December 1999 by linkage with the Swedish Population Register. A total of 6950 fishermen and 5818 fishermen's wives born in 1920 or later, living in Sweden, and still alive on 31 December 1999 constituted the study base (table 1).

\section{Questionnaire}

A postal questionnaire was sent in 2000 to all 12768 potential participants. The response rates after two reminders are shown in table 1 . The participants were asked to specify, with respect to calendar year and location, their skeletal fractures from 25 years of age on (table 2). Furthermore, we asked for current fish consumption as specified for fish species and whether it had been caught in the Baltic Sea or not. Moreover, we asked about potential confounders such as age at menopause, body height, body weight, heredity with respect to skeletal fractures, physical exercise, drug intake (especially cortisone and estrogen replacement therapy), smoking habits, alcohol intake, and consumption of dairy products. The median menopausal age for the

Table 1. Questionnaire responses of the cohorts of Swedish fishermen and their wives from the west and east coasts and comparisons between the respondents and nonrespondents with respect to age distribution, percentage of persons deceased since the time of the postal questionnaire, and the percentage of persons with hospitalized fractures.

\begin{tabular}{|c|c|c|c|c|c|c|c|c|c|c|c|c|c|}
\hline \multirow[t]{3}{*}{ Group } & \multirow{3}{*}{$\begin{array}{c}\text { Eligible } \\
\text { subjects a } \\
\text { (N) }\end{array}$} & \multicolumn{6}{|c|}{ Respondents } & \multicolumn{6}{|c|}{ Nonrespondents } \\
\hline & & \multirow[t]{2}{*}{$\mathrm{N}$} & \multirow[t]{2}{*}{$\%$} & \multicolumn{2}{|c|}{ Birth year } & \multirow{2}{*}{$\begin{array}{l}\text { Deceased } \\
\text { after } \\
\text { study } \\
\text { period } \\
(\%)\end{array}$} & \multirow{2}{*}{$\begin{array}{l}\text { Persons } \\
\text { with hos- } \\
\text { pitalized } \\
\text { fractures }{ }^{c} \\
(\%)\end{array}$} & \multirow[t]{2}{*}{$\mathrm{N}$} & \multirow[t]{2}{*}{$\%$} & \multicolumn{2}{|c|}{ Birth year } & \\
\hline & & & & Median & Range & & & & & Median & Range & $\begin{array}{l}\text { study } \\
\text { period b } \\
(\%)\end{array}$ & $\begin{array}{l}\text { pitalized } \\
\text { fractures } \\
(\%)\end{array}$ \\
\hline \multicolumn{14}{|l|}{ Fishermen } \\
\hline West coast & 4854 & 2436 & 50.2 & 1944 & 1920-1973 & 1.7 & 4.1 & 2418 & 49.8 & 1945 & $1920-1973$ & 3.3 & 4.7 \\
\hline East coast & 2096 & 1082 & 51.6 & 1946 & 1920-1971 & 1.0 & 3.4 & 1014 & 48.4 & 1948 & $1920-1972$ & 3.0 & 4.4 \\
\hline \multicolumn{14}{|c|}{ Fishermen's wives } \\
\hline West coast & 4217 & 2431 & 57.6 & 1942 & 1920-1971 & 1.1 & 3.7 & 1786 & 42.4 & 1942 & $1920-1971$ & 3.8 & 4.6 \\
\hline East coast & 1602 & 954 & 59.6 & 1944 & 1920-1969 & 0.7 & 3.4 & 648 & 40.4 & 1945 & $1920-1972$ & 2.0 & 3.9 \\
\hline
\end{tabular}

a Persons born in 1920 or later, living in Sweden, and alive on 31 December 1999.

b Deceased between January 2000 and January 2002.

c During the period 1987-1996. 
Table 2. Number of fractures, persons, and person-years at risk in the cohorts of Swedish fishermen and their wives from the west and east coasts.

\begin{tabular}{|c|c|c|c|c|c|c|}
\hline \multirow[t]{3}{*}{ Group } & \multicolumn{6}{|c|}{ Fractures } \\
\hline & \multirow[t]{2}{*}{ Wrist } & \multirow[t]{2}{*}{ Hip } & \multirow[t]{2}{*}{ Vertebral } & \multicolumn{3}{|c|}{ All osteoporotic } \\
\hline & & & & $\mathrm{Na}^{\mathrm{a}}$ & $\begin{array}{l}\text { Num- } \\
\text { ber of } \\
\text { person- } \\
\text { years } \\
\text { at risk }{ }^{b}\end{array}$ & $\begin{array}{c}\text { Num- } \\
\text { ber of } \\
\text { per- } \\
\text { sons }{ }^{c}\end{array}$ \\
\hline \multicolumn{7}{|l|}{ Fishermen } \\
\hline $\begin{array}{l}\text { West coast } \\
\text { East coast }\end{array}$ & $\begin{array}{l}92 \\
40\end{array}$ & $\begin{array}{l}33 \\
14\end{array}$ & $\begin{array}{l}32 \\
13\end{array}$ & $\begin{array}{r}148 \\
64\end{array}$ & $\begin{array}{l}73265 \\
31256\end{array}$ & $\begin{array}{l}2432 \\
1080\end{array}$ \\
\hline \multicolumn{7}{|c|}{ Fishermen's wives } \\
\hline $\begin{array}{l}\text { West coast } \\
\text { East coast }\end{array}$ & $\begin{array}{r}198 \\
64\end{array}$ & $\begin{array}{r}48 \\
9\end{array}$ & $\begin{array}{l}25 \\
14\end{array}$ & $\begin{array}{r}248 \\
84\end{array}$ & $\begin{array}{l}77166 \\
29162\end{array}$ & $\begin{array}{r}2428 \\
952\end{array}$ \\
\hline
\end{tabular}

a $A$ person with more than one of the aforementioned fractures contributes with only one fracture.

b In the analyses of all osteoporotic fractures.

c Included in the analyses of all osteoporotic fractures.

Table 3. Distributions of potential confounders in the cohorts of fishermen and their wives from the Swedish west and east coasts.

\begin{tabular}{|c|c|c|c|c|}
\hline \multirow{2}{*}{$\begin{array}{l}\text { Potential } \\
\text { confounder }\end{array}$} & \multicolumn{2}{|c|}{ Fishermen } & \multicolumn{2}{|c|}{ Fishermen's wives } \\
\hline & $\begin{array}{c}\text { West } \\
\text { coast } \\
(\%)\end{array}$ & $\begin{array}{c}\text { East } \\
\text { coast } \\
(\%)\end{array}$ & $\begin{array}{c}\text { West } \\
\text { coast } \\
(\%)\end{array}$ & $\begin{array}{c}\text { East } \\
\text { coast } \\
(\%)\end{array}$ \\
\hline \multicolumn{5}{|l|}{ Body mass index } \\
\hline $\begin{array}{l}\leq 22 \mathrm{~kg} / \mathrm{m}^{2} \\
>22-30 \mathrm{~kg} / \mathrm{m}^{2} \\
>30 \mathrm{~kg} / \mathrm{m}^{2}\end{array}$ & $\begin{array}{r}4.9 \\
80.4 \\
14.7\end{array}$ & $\begin{array}{r}5.4 \\
75.9 \\
18.7\end{array}$ & $\begin{array}{l}16.4 \\
72.1 \\
11.4\end{array}$ & $\begin{array}{l}12.6 \\
69.6 \\
17.7\end{array}$ \\
\hline \multicolumn{5}{|l|}{ Heredity ${ }^{a}$} \\
\hline $\begin{array}{l}\text { Yes } \\
\text { No }\end{array}$ & $\begin{array}{l}23.1 \\
76.9\end{array}$ & $\begin{array}{l}21.0 \\
79.0\end{array}$ & $\begin{array}{l}29.0 \\
71.0\end{array}$ & $\begin{array}{l}27.2 \\
72.8\end{array}$ \\
\hline \multicolumn{5}{|l|}{ Physical exercise ${ }^{b}$} \\
\hline $\begin{array}{l}\text { No } \\
\text { Yes }\end{array}$ & $\begin{array}{l}31.6 \\
68.4\end{array}$ & $\begin{array}{l}41.1 \\
58.9\end{array}$ & $\begin{array}{l}20.7 \\
79.3\end{array}$ & $\begin{array}{l}23.0 \\
77.0\end{array}$ \\
\hline \multicolumn{5}{|l|}{ Cortisone use ${ }^{c}$} \\
\hline $\begin{array}{l}\geq 3 \text { months } \\
\text { Other }\end{array}$ & $\begin{array}{r}6.7 \\
93.3\end{array}$ & $\begin{array}{r}8.3 \\
91.7\end{array}$ & $\begin{array}{r}8.0 \\
92.0\end{array}$ & $\begin{array}{r}9.2 \\
90.8\end{array}$ \\
\hline $\begin{array}{l}\text { Estrogen replacemen } \\
\text { therapy }^{d}\end{array}$ & - & - & 48.0 & 50.7 \\
\hline \multicolumn{5}{|l|}{ Smoking } \\
\hline $\begin{array}{l}\text { Ever } \\
\text { Never }\end{array}$ & $\begin{array}{l}68.6 \\
31.4\end{array}$ & $\begin{array}{l}76.6 \\
23.4\end{array}$ & $\begin{array}{l}45.1 \\
54.9\end{array}$ & $\begin{array}{l}56.8 \\
43.2\end{array}$ \\
\hline \multicolumn{5}{|l|}{ Alcohol intake } \\
\hline $\begin{array}{l}>100 \text { (men) or } 50 \\
\text { (women) g/week } \\
\text { Other }\end{array}$ & $\begin{array}{r}8.6 \\
91.4\end{array}$ & $\begin{array}{l}12.5 \\
87.5\end{array}$ & $\begin{array}{l}10.0 \\
90.0\end{array}$ & $\begin{array}{l}12.5 \\
87.5\end{array}$ \\
\hline \multicolumn{5}{|c|}{ Intake of dairy products ${ }^{\mathrm{e}}$} \\
\hline $\begin{array}{l}\text { No } \\
\text { Yes }\end{array}$ & $\begin{array}{r}9.0 \\
91.0\end{array}$ & $\begin{array}{r}8.0 \\
92.0\end{array}$ & $\begin{array}{l}11.0 \\
89.0\end{array}$ & $\begin{array}{l}10.9 \\
89.1\end{array}$ \\
\hline
\end{tabular}

a Yes: father or mother had a fracture after the age of 25 years.

${ }^{\mathrm{b}} \mathrm{No}$ : walked less than $5 \mathrm{~km} /$ day and had no other physical exercise.

c Yes: at any period used cortisone drugs 3 months or longer.

d Cumulative incidence of the women at least 55 years of age at the time

the questionnaire was filled out.

e No: $\leq 1$ glass of milk/day and $\leq 1$ slices of cheese/day. women at least 55 years of age at the time of filling out the questionnaire was 51 years for both the east- and west-coast cohorts. The distributions for the other potential confounders are shown in table 3.

The ethics committee of the Lund University approved the study.

\section{Nonrespondents}

The age distribution of the nonrespondents and respondents was almost identical (table 1). Linkage with the Swedish Fracture Register at the National Board of Health and Welfare, comprising all hospitalized fractures, revealed that, during the period 1987-1996, the nonrespondents had been treated in a hospital ward for a skeletal fracture to a somewhat larger extent than the respondents. Moreover, renewed linkage with the Swedish Population Register until January 2002 revealed that a larger fraction of the nonrespondents than of the respondents had died since the postal questionnaire had been distributed. These differences between the respondents and nonrespondents were, however, not differential with respect to coastal area.

\section{Statistical methods}

The incidence rate ratio (IRR) and $95 \%$ confidence intervals $(95 \% \mathrm{CI})$ were estimated for fractures with the use of Poisson regression models using EGRET software (Statistics and Epidemiology Research Corporation, Seattle, WA, USA). The fracture incidence rates for specific skeletal locations were based on allocated fractures and person-years at risk from 25 years of age until the time of fracture or the end of the follow-up (table 2). Hip, vertebral, and wrist fractures were classified as osteoporotic fractures. When the incidence rates for osteoporotic fractures were calculated, the follow-up stopped at the time of the first fracture within this category or at the end of the follow-up period.

In the analyses, we estimated the effect of cohort affiliation (east coast versus west coast) and the total intake of fish on the risk of developing osteoporotic fractures among the fishermen and their wives, respectively. In addition, for the east-coast cohorts, we also estimated the effects of intake of fatty fish from the Baltic Sea.

Age is a well-known strong risk factor for osteoporotic fractures, and, in addition, it is known to be associated with serum levels of POC. Therefore we always present both the unadjusted and adjusted estimates. On the basis of the results of the univariate analyses, we used a more-detailed age categorization for the women $(25-50,51-60,61-70$, and 71-80 years for women, but $25-70$, and 71-80 years for men). Moreover, as potential confounders, we considered the following 
variables: body mass index (BMI), heredity for fractures, physical exercise, cortisone drugs, estrogen replacement therapy, age at menopause, smoking habits, alcohol intake, and consumption of dairy products (table 3). If these variables were associated with the risk of fracture $(\mathrm{P}<0.15)$, we included them in the models, one at a time. If the age-adjusted incidence rate ratio changed by at least $15 \%$, the confounder was kept in the model. In addition, we tested whether these factors modified the effect of cohort affiliation and the intake of fatty fish from the Baltic Sea by including interaction terms in the models.

\section{Results}

The univariate analyses indicated an effect of BMI, heredity for fractures, cortisone drugs, smoking habits, and consumption of dairy products on osteoporotic fractures among the fishermen (all P-values $<0.15$, data not shown), whereas physical exercise and alcohol intake were not associated with fracture incidence. Among the fishermen's wives only heredity for fractures, menopausal age, and smoking habits showed an effect. However, in the multivariate models none of the confounders, except age, changed the risk estimates more than marginally. Thus we present the crude and age-adjusted risk estimates.

There were no effects of cohort affiliation on all osteoporotic fractures among the fishermen (age-adjusted IRR 1.02 , 95\% CI 0.76-1.37, table 4) or their wives (age-adjusted IRR 0.95, 95\% CI 0.74-1.22).

An analysis within the cohort of east-coast fishermen showed no association between the consumption of fatty fish from the Baltic Sea and the incidence of osteoporotic fractures (table 5). On the other hand, for the east-coast fishermen's wives, a positive association was indicated (table 6). The wives who had consumed more than one meal of fatty fish from the Baltic Sea per month had an increased incidence as compared with the wives who ate, at most, one such meal per month (ageadjusted IRR $1.68,95 \%$ CI 1.00-2.84, data not in table). Change in the consumption of fatty fish from the Baltic Sea over time was not associated with cohort affiliation or current consumption habits. Thus no adjustments were made for this factor.

The consumption of other types of fish was not associated with an increased fracture incidence, as illustrated by the age-adjusted IRR of 1.14 (95\% CI $0.84-$ 1.56) for the west-coast fishermen's wives with the highest total fish consumption ( $>12$ meals per month) as compared with the west-coast fishermen's wives with an intake of $<8$ meals per month.

\section{Discussion}

The main finding of our study was that the women with a relatively high consumption of POC-contaminated fatty fish from the Baltic Sea tended to have an increased incidence of osteoporotic fractures. No such association was seen for the men. On the other hand, the lack of difference in fracture rate between the fishermen's wives from the east and west coasts argues against a role for POC exposure.

In a previous register-linkage study we observed a significantly increased incidence of hospitalized vertebral fractures among fishermen's wives from the Swedish east coast as compared with the incidence of fishermen's wives from the Swedish west coast, and a simi-

Table 4. Crude and age-adjusted incidence rate ratios (IRR) for the comparisons of osteoporotic fractures between the cohorts of west and east coast fishermen and their wives. $(95 \% \mathrm{Cl}=95 \%$ confidence interval)

\begin{tabular}{lccccc}
\hline Cohort affiliation & \multicolumn{2}{c}{ Crude } & & \multicolumn{2}{c}{ Age-adjusted } \\
\cline { 2 - 3 } \cline { 5 - 6 } & IRR & $95 \% \mathrm{Cl}$ & & IRR & $95 \% \mathrm{Cl}$ \\
\hline Fishermen & & & & \\
$\quad$ West coast & 1.00 &. & & $1.00^{\mathrm{a}}$ &. \\
East coast & 1.01 & $0.76-1.36$ & & 1.02 & $0.76-1.37$ \\
Fishermen's wives & & & & \\
West coast & 1.00 &. & & $1.00^{\mathrm{b}}$ & \\
East coast & 0.89 & $0.70-1.15$ & & 0.95 & $0.74-1.22$ \\
\hline
\end{tabular}

Age categories: $25-70$ and $71-80$ years.

${ }^{b}$ Age categories: $25-50,51-60,61-70$, and $71-80$ years.

Table 5. Crude and age-adjusted incidence rate ratios (IRR) for osteoporotic fractures within the cohort of east coast fishermen with respect to consumption of fatty fish from the Baltic Sea. $(95 \% \mathrm{Cl}=95 \%$ confidence interval)

\begin{tabular}{|c|c|c|c|c|c|}
\hline \multirow{2}{*}{$\begin{array}{l}\text { Fatty fish from } \\
\text { the Baltic Sea }\end{array}$} & \multirow[t]{2}{*}{$\mathrm{N}$} & \multicolumn{2}{|c|}{ Crude } & \multicolumn{2}{|c|}{ Age-adjusted a } \\
\hline & & IRR & $95 \% \mathrm{Cl}$ & IRR & $95 \% \mathrm{Cl}$ \\
\hline 0-2 meals/month & 419 & 1.00 & $\cdot$ & 1.00 & $\cdot$ \\
\hline$>2-6$ meals/month & 410 & 0.61 & $0.34-1.07$ & 0.60 & $0.34-1.07$ \\
\hline$>6$ meals/month & 251 & 0.64 & $0.35-1.20$ & 0.63 & $0.34-1.18$ \\
\hline
\end{tabular}

age categories: $25-70$ and $71-80$ years.

Table 6. Crude and confounder-adjusted incidence rate ratios (IRR) for osteoporotic fractures within the cohort of east coast fishermen's wives with respect to consumption of fatty fish from the Baltic Sea.

\begin{tabular}{lccccccc}
\hline $\begin{array}{l}\text { Fatty fish from } \\
\text { the Baltic Sea }\end{array}$ & $N$ & \multicolumn{2}{c}{ Crude } & & \multicolumn{2}{c}{ Age-adjusted a } \\
\cline { 3 - 4 } \cline { 7 - 8 } & & IRR & $95 \% \mathrm{Cl}$ & & IRR & $95 \% \mathrm{Cl}$ \\
\hline $0-1$ meals/month & 364 & 1.00 & $\cdot$ & & 1.00 & $\cdot$ \\
$>1-<4$ meals/month & 368 & 1.76 & $1.00-3.09$ & & 1.63 & $0.93-2.87$ \\
$\geq 4$ meals/month & 220 & 2.18 & $1.22-3.91$ & & 1.75 & $0.97-3.15$ \\
\hline
\end{tabular}

a Age categories $25-50,51-60,61-70$, and $71-80$ years. 
lar, but weaker and less certain, tendency for the eastcoast fishermen (22). There were fewer osteoporotic fractures in our present study than in the previous register-linkage study, which was based on a historical cohort that allowed the inclusion of fractures also for persons who died later. In contrast, our present study was based on a cross-section of the same cohort, comprised only of persons alive and living in Sweden at the time the questionnaire was distributed. Thus the numbers of hip fractures that occur at older ages, and are related with high mortality, were considerably lower in the present study than in the previous one. On the other hand, in the previous study, only fractures that could be retrieved from the in-patient Swedish fracture register were included, while, in the present study, we relied on the participants' own recall of fractures, the result being a larger number of wrist fractures in the present study.

Due to the relatively high proportion of nonparticipants in our present study, possible selection bias has to be considered. There were, however, no differences in the age distributions of the participants and nonparticipants. In addition, the percentage of persons with hospitalized fractures and the fraction of persons who had died since the postal questionnaire was distributed were higher among the nonrespondents than among the respondents, but not differential with respect to coastal stretch. Thus we do not believe that selection bias was an issue of major concern when cohort affiliation was used as the exposure variable.

In our present study current consumption of fatty fish from the Baltic Sea was used as an indirect measure of exposure to POC. A more adequate measure would probably have been the fish consumption habits decades earlier. However, previous studies performed in the same cohorts showed that the quality of the fish consumption assessment did not increase by using dietary recall data instead of current consumption data (23). Moreover, a change in fish consumption habits over time was not associated with cohort affiliation or the current consumption of fatty fish from the Baltic Sea.

It was possible to obtain information on several potential confounders from the questionnaire. Age was the most obvious one, as both the fracture incidence and fish consumption habits were clearly age-related. None of the other factors changed the effect estimates in the multivariate models more than marginally. It is, however, important to be aware of the limitation that current BMI, physical exercise habits, alcohol intake, and intake of dairy products are assumed to be relevant for the entire follow-up period.

It can be argued that the present finding of exposureresponse associations between dietary intake of fatty fish from the Baltic Sea and the increased incidence rate ratios for fractures among the women are supported by the previous finding of an increased incidence of vertebral fractures among east-coast fishermen's wives (22). On the other hand, it is puzzling why there was no effect of cohort affiliation in the present study. A hypothetical explanation could be that also consumption of fish other than fatty fish from the Baltic Sea would constitute a risk factor for fractures. However, available data do not support this possibility. There was no indication of an association between fish consumption and osteoporotic fractures among the west-coast fishermen's wives.

The results of our present study are somewhat contradicting, and they provide only minor support for an association between POC exposure through the consumption of contaminated fish and an increased risk of osteoporotic fractures. A nested case-referent study of osteoporotic fractures within the fishermen's cohort, using biomarkers of POC exposure as a complement to dietary interviews, could contribute to a better understanding. Moreover, ongoing bone density studies in the same population may also be beneficial when the possible impact of POC exposure on human bone metabolism is being assessed.

\section{Acknowledgments}

Financial support was given by the European Commission RD Life Science Program (QLK4-CT-2000-0261), the Swedish Research Council for Medicine, the Swedish Research Council for Environment, Agricultural Sciences and Spatial Planning, the Medical Faculty, Lund University, and Region Skåne funds.

We thank Ann-Kathrine Alveblom, Beverley Embrey, Yulia Lindholm, and Thérèse Mikoczy for their technical and secretarial assistance with the postal questionnaire.

\section{References}

1. Obrant KJ, Bengnér U, Johnell O, Nilsson BE, Sernbo I. Increasing age-adjusted risk of fragility fractures: a sign of increasing osteoporosis in successive generations? Calcif Tissue Int 1989;44:157-67.

2. Cummings SR, Nevitt MC, Browner WS, Stone K, Fox KM, Ensrud KE, et al. Risk factors for hip fracture in white women. N Engl J Med 1995;332:767-73.

3. Kannus P, Parkkari J, Niemi S, Palvanen M. Epidemiology of osteoporotic ankle fractures in elderly persons in Finland. Ann Intern Med 1996;125:975-78.

4. Boyce WJ, Vessey MP. Rising incidence of fracture of the proximal femur. Lancet 1985;1:150-51.

5. Lips P. Epidemiology and predictors of fractures associated with osteoporosis Am J Med 1997;103(2):3-8. 
6. Jamsa T, Viluksela M, Tuomisto JT, Tuomisto J, Tuukanen J. Effects of 2,3,7,8-tetrachlorodibenzo-p-dioxin on bone in two rat strains with different aryl hydrocarbon receptor structures. J Bone Miner Res 2001;16;1812-20.

7. Lind PM, Eriksen EF, Sahlin L, Edlund M, Örberg J. Effects of the antiestrogenic environment pollutant 3,3',4,4',5-pentachlorobiphenyl (PCB\#126) in rat bone and uterus: diverging effects in ovariectomized and intact animals. Toxicol Appl Pharmacol 1999;154:236-44.

8. Lind PM, Larsson S, Oxlund H, Håkansson H, Nyberg K, Eklund $\mathrm{T}$, et al. Change of bone tissue composition and impaired bone strength in rats exposed to 3,3',4,4',5-pentachlorobiphenyl (PCB-126). Toxicology 2000;150:41-51.

9. Lind M. Organochlorines and bone: effects of organochlorines on bone tissue morphology, composition and strength [dissertation]. Uppsala (Sweden): Acta Universitas Upsaliensis; 2000.

10. Turner RT, Riggs BL, Spelsberg TC. Skeletal effects of estrogen. Endocr Rev 1994;15:275-96.

11. Slemenda CW, Longcope C, Zhou L, Hui SLO, Peacock M, Johnston CC. Sex steroids and bone mass in older men. J Clin Invest 1997;100:1755-9.

12. Birnbaum LS, Cummings AM. Dioxins and endometriosis: a plausible hypothesis. Environ Health Perspect 2002;110:1521.

13. Cripps DJ, Peters HA, Gocmen A, Dogramic I. Porphyria turcica due to hexachlorobenzene: a 20 to 30 year follow-up study on 204 patients. Br J Dermatol 1984;111:413-22.

14. Miller RW. Congenital PCB poisoning: a reevaluation. Environ Health Perspect 1985;60:211-14.

15. Svensson BG, Nilsson A, Hansson M, Rappe C, Ảkesson B, Skerfving S. Exposure to dioxins and dibenzofurans through the consumption of fish. N Engl J Med 1991;324:8-12.

16. Asplund L, Svensson BG, Nilsson A, Eriksson U, Jansson B, Jensen $\mathrm{S}$, et al. Polychlorinated biphenyls, 1,1,1-trichloro- 2,2-bis(p-chlorophenyl)ethane (p,p'-DDT) and 1,1-dichloro2,2-bis(p-chlorophenyl)- ethylene (p,p'-DDE in human plasma related to fish consumption. Arch Environ Health 1994;49:477-86.

17. Svensson BG, Nilsson A, Jonsson E, Schütz, Åkesson B, Hagmar L. Fish consumption and exposure to persistent organochlorine compounds, mercury, selenium and methylamines among Swedish fishermen. Scand J Work Environ Health 1995;21:96-105.

18. Rylander L, Hagmar L. Mortality and cancer incidence among women with a high consumption of fatty fish contaminated with persistent organochlorine compounds. Scand J Work Environ Health 1995;21:419-26.

19. Bergqvist P, Bergek S, Hallbäck H, Rappe C, Slorach S. Dioxins in cod and herring from the seas around Sweden. Chemosphere 1989;19:513-16.

20. Grimvall W, Rylander L, Nilsson-Ehle P, Nilsson U, Strömberg U, Hagmar L, et al. Monitoring of polychlorinated biphenyls in human blood plasma with respect to age, lactation and fish consumption; methodology developments. Arch Environ Contam Toxicol 1997;32:329-36.

21. Rylander L, Dyremark E, Strömberg U, Östman C, Hagmar L. The impact of age, lactation and dietary habits on PCB in plasma in Swedish women. Sci Total Environ 1997;207:5561.

22. Alveblom A-K, Rylander L, Johnell O, Hagmar L. Incidence of hospitalized osteoporotic fractures in cohorts with high dietary intake of persistent organochlorine compounds. Int Arch Occup Environ Health 2003;76:246-8.

23. Rylander L, Strömberg U, Hagmar L. Agreement between reported fish consumption obtained by two interviews and its impact on the results in a reproduction study. Eur J Epidemiol 1998;14: 93-7.

Received for publication: 24 June 2003 